\title{
Removal of Lactic Acid from Acid Whey Using Electrodialysis
}

George Q. Chen ${ }^{1}$, Franziska I.I. Eschbach ${ }^{1}$, Mike Weeks ${ }^{2}$, Sally L. Gras ${ }^{1,3}$, Sandra E. Kentish ${ }^{1 *}$

1 ARC Dairy Innovation Hub, Department of Chemical and Biomolecular Engineering, University of Melbourne, Victoria 3010, Australia.

2 Dairy Innovation Australia Ltd., Werribee, Victoria 3030, Australia.

${ }^{3}$ Bio21 Molecular Science and Biotechnology Institute, The University of Melbourne, Victoria 3010, Australia.

Keywords: Dairy; Acid whey; Lactate; Demineralisation; Electrodialysis.

*Corresponding Author

Prof Sandra Kentish

Tel: +61383446682

Fax: +61383444153

E-mail address: sandraek@unimelb.edu.au 


\section{ABSTRACT}

The processing of acid whey, a by-product of cream cheese making, casein production and strained yogurt manufacture, has been a challenge in the dairy industry. The high lactic acid concentration causes operational problems in downstream spray drying operations due to increased powder stickiness. In this work, electrodialysis, a well proven demineralisation technology is used to remove the lactate ions from acid whey. If the ratio of lactic acid to lactose is to be reduced to the same level found in sweet whey, $80 \%$ of the lactate ions must be removed. For both laboratory prepared solutions and acid whey samples, the lactate ions were removed at a slower rate compared to other anions present in the system. Increasing the $\mathrm{pH}$ (from pH 4.6 to $\mathrm{pH}$ 6) of the feed solution led to a small enhancement in the rate of lactate ions removal at $5^{\circ} \mathrm{C}$. No impact was observed, however, at 30 and $45^{\circ} \mathrm{C}$ where membrane resistance and solution viscosity is lower. To achieve the same level of lactate ion removal, the processing time in a batch process was three times shorter at $45^{\circ} \mathrm{C}$, compared to that at $5^{\circ} \mathrm{C}$. This means that significantly less membrane area is required in a continuous industrial electrodialysis operation. The energy consumption $(\sim 0.014 \mathrm{kWh} / \mathrm{kg}$ whey processed) for achieving $90 \%$ demineralization of the acid whey was comparable to the energy requirement reported for sweet whey demineralization in a typical commercial electrodialysis unit, illustrating the feasibility of this approach. 


\section{INTRODUCTION}

Acid whey is a by-product of cream cheese and strained yoghurt manufacture and is also produced from chemical acidification of milk in casein production. This whey stream contains about $20 \%$ of the protein $(\sim 1 \% \mathrm{~m} / \mathrm{v})$ and most of the lactose (LT) $(\sim 4.4 \% \mathrm{~m} / \mathrm{v})$ from the original input milk [1]. Sweet whey is generated from rennet cheese manufacture, and while similar in composition, acid whey can contain up to 16 times the concentration of lactic acid (LA) to that in sweet whey [1]. Traditionally, sweet whey is further processed to make whey powder, lactose, whey protein concentrate and demineralised whey powder. One of the essential steps for manufacturing these products is the use of spray dryers. The presence of lactic acid in acid whey prevents a similar process as the acid whey makes the resulting whey powder more susceptible to moisture absorption [2-4], due to the hygroscopic nature of the lactate ions $[5,6]$ and this leads to the formation of powder agglomerates and sticky deposits within the dryer that cannot be tolerated in normal operation. Consequently, acid whey is often used as a stockfeed to neighbouring farms or discharged as effluent, rather than providing a valuable source of protein for human diet consumption.

The formation of these sticky deposits is a function of the proportion of lactose that is present in a crystalline rather than an amorphous phase, which in turn depends upon the glass transition temperature of the powder, relative to the dryer operating temperature. In turn, this glass transition temperature is related to the level of lactic acid present in the feed [5]. For example, the temperature of sticking increases from $\sim 70^{\circ} \mathrm{C}$ to $\sim 95^{\circ} \mathrm{C}$, when the mass ratio of lactic acid to lactose decreases from $\sim 0.2 \mathrm{~g}$ LA/g LT in acid whey to $\sim 0.04 \mathrm{~g}$ LA/g LT in sweet whey powder [5].

The effect of lactic acid in the crystallisation process of lactose/protein powders has previously been studied by Saffari and Langrish [7] and Shrestha et al. [2] who used laboratory scale spray drying units. The ratio of LA to LT was found to correlate well with a decline in spray dryer powder recovery and the glass transition temperature of the recovered powder. Typically, by increasing the concentration of lactic acid from $\sim 2 \mathrm{~g} / \mathrm{l}$ (in sweet whey) to $\sim 6 \mathrm{~g} / \mathrm{l}$ (in acid whey), the yield of the sprayed dried powder decreased by $\sim 20 \%$ [7]. At the same time, the glass transition temperature decreased significantly. Similar 
trends were reported by Shrestha et al. [2], who observed that a free flowing powder could be produced only if the lactose solutions contained less than $4.2 \mathrm{~g}$ of lactic acid per $100 \mathrm{~g}$ lactose. This is equivalent to the ratio of LA/LT in sweet whey.

Therefore, a reduction in lactic acid concentration is necessary before acid whey can be efficiently processed by downstream spray drying unit operations. The neutralization of the lactic acid has been studied as a potential approach to resolve this issue $[2,3]$ but this approach results in bitter and astringent flavours. Alternatively, electrodialysis has been successfully demonstrated to recover lactic acid from fermentation broths [8, 9], as well as to demineralise sweet whey prior to whey powder production $[10,11]$. This unit operation relies on the transfer of charged species from the diluate (feed) stream to a concentrate stream, through a series of cation and anion selective membranes under a constantly applied electrical potential.

While lactose molecules are uncharged, lactic acid is a weak acid that can dissociate into its conjugate base (a lactate ion, $\mathrm{CH}_{3} \mathrm{CH}(\mathrm{OH}) \mathrm{COO}^{-}$) and protons (Equation 1). It is expected that lactose will be retained in the diluate stream while lactate and other charged ions will be transferred to the concentrate, effectively demineralising the acid whey.

The dissociation of lactic acid is given by the Henderson-Hasselbalch equation:

$p H=p K_{a}+\log \frac{\left[\mathrm{CH}_{3} \mathrm{CHOHCOO}^{-}\right]}{\left[\mathrm{CH}_{3} \mathrm{CHOHCOOH}\right]}$

where the $p K_{a}$ of lactic acid at $25^{\circ} \mathrm{C}$ is 3.86 [12]. The association constant at a different temperature can then be estimated by the following correlation [13]:

$-d\left(p K_{a}\right) / d T=\left(p K_{a}-0.9\right) / T \pm 0.004$

Williams et al. [14] patented an electrodialysis approach that used a three compartment stack to reduce the acidity of acid whey for use in ice cream, by neutralisation with caustic solution. Bipolar membranes allow a salt to be split into the corresponding alkali and acid during electrodialysis and this approach has also been used to split salts such as ammonium 
lactate, formed during fermentation of whey permeate, into lactic acid and ammonium hydroxide[15]. The focus of this prior work with electrodialysis has either been to neutralise the acidity of a whey solution by removing protons, or to provide high purity lactic acid as a product from a high concentration fermentation broth. Conversely, the focus of the present work is the removal of lactate anions at relatively low concentration from a whey solution. The reduction in the concentration of lactate potentially allows for the processing of acid whey in a similar manner as sweet whey, allowing the proteins and lactose to be recovered for sale. 


\section{EXPERIMENTAL}

\subsection{Materials}

Raw acid whey samples were obtained from a dairy processing company in Victoria, Australia. The acid whey was treated in a pilot plant at Dairy Innovation Australia Ltd (Werribee, Victoria Australia) using a centrifugal separator (GEA Westfalia Separator, Model SC 6-01-576) to remove the whey cream and most of the casein fines. This stream is referred to as the skimmed acid whey. Part of the skimmed acid whey was further filtered in the laboratory through a $10 \mathrm{kDa}$ ultrafiltration membrane (Koch) so that the residual fat and protein are removed. This stream is referred to as the acid whey UF permeate sample. This standardises the acid whey samples and reduces the possibility of microorganism growth [16] and protein fouling in the electrodialysis stack [17, 18]. All acid whey samples were refrigerated at $2-4{ }^{\circ} \mathrm{C}$. The skimmed acid whey samples were used within two weeks while the ultrafiltered permeate samples were used within four weeks.

The composition of acid whey was found to be consistent with that reported in the literature, as shown in Table 1. Fats were expected to be removed completely by the ultrafiltration process. Protein was also not detected in the ultrafiltration permeate. The concentrations of lactose and lactate ions decreased slightly after ultrafiltration, while all other ions passed through the membrane. In a typical dairy processing facility, ultrafiltration is employed after the whey cream is separated from the raw whey by a centrifugal separator, in order to recover the protein for the manufacture of whey protein concentrate and whey protein isolate, similar to the process applied here. The skimmed acid whey and the ultrafiltered acid whey samples were both used in this work, to understand the impact of the residual fats and protein on the performance of the electrodialysis unit.

Purified water (13.2 M $\Omega-\mathrm{cm}$, Millipore) was used for preparing all solutions used in this work. Model solutions, described as $L A+L T+N a C l$, were prepared by mixing lactic acid (85\%, Ajax Finechem) with lactose ( $\geq 99.8 \%$, Ajax Finechem) to mimic the concentration of lactate ions and lactose in acid whey. In addition, sodium chloride ( $\mathrm{NaCl},>99.5 \%$, Merck) was added to mimic the conductivity of acid whey (i.e. $7.8 \mathrm{mS} / \mathrm{cm}$ ). The $\mathrm{pH}$ of these artificial solutions was also adjusted to 4.6 or 6 using an appropriate amount of $10 \mathrm{M} \mathrm{NaOH}$. The composition and 
general characteristics of the model artificial solution are also shown in Table 1 . Solutions of sodium sulphate $\left(\mathrm{Na}_{2} \mathrm{SO}_{4}\right.$ Ajax Finechem) $(20 \mathrm{~g} / \mathrm{L})$ and $\mathrm{NaCl}(5.5 \mathrm{~g} / \mathrm{L})$ were prepared as the electrode rinse solutions and the concentrate solutions respectively.

The cation exchange membranes (Neosepta $\mathrm{CMB}$ ) and anion exchange membranes (Neosepta AHA) were purchased from Astom (Japan). These membranes were selected because of their wide $\mathrm{pH}$ tolerance and temperature stability (Table 2). The relatively high electrical resistance means that the energy consumption and separation performance can be assessed in a conservative manner. All membranes were preconditioned by soaking the membranes in a 3 wt\% $\mathrm{NaCl}$ solution overnight to allow for membrane hydration and expansion.

Table 1: The composition of sweet whey, acid whey, and the model artificial solution used in this work.

\begin{tabular}{|c|c|c|c|c|c|c|}
\hline \multirow[b]{2}{*}{ Component } & \multirow[b]{2}{*}{ Unit } & \multirow[b]{2}{*}{$\begin{array}{c}\text { Sweet } \\
\text { Whey } \\
{[1,19-22]}\end{array}$} & \multicolumn{4}{|c|}{ Acid Whey } \\
\hline & & & Skimmed & $\begin{array}{c}\text { UF } \\
\text { Permeate }\end{array}$ & $\begin{array}{c}\text { Range } \\
\text { Reported } \\
\text { by others }^{(a)} \\
{[1,7,19} \\
20,23-25]\end{array}$ & $\begin{array}{c}\text { Artificial } \\
\text { Solution } \\
\text { (LT+LA + } \\
\mathrm{NaCl})\end{array}$ \\
\hline Total Solid & $\% \mathrm{~m} / \mathrm{v}$ & $6.3-7.74$ & $5.22 \pm 0.09$ & $3.42 \pm 0.14$ & $5-6.4$ & - \\
\hline Fat & $\% \mathrm{~m} / \mathrm{v}$ & $0.05-0.5$ & $0.09^{(b)}$ & - & $0.003-0.38$ & - \\
\hline Minerals & $\% \mathrm{~m} / \mathrm{v}$ & $0.2-0.59$ & $0.47 \pm 0.01$ & $0.46 \pm 0.01$ & $0.5-0.7$ & - \\
\hline Total Protein & $\% \mathrm{~m} / \mathrm{v}$ & $0.6-1$ & $0.42 \pm 0.02^{(c)}$ & $0^{(c)}$ & $0.8-1$ & - \\
\hline Lactate & $\mathrm{mg} / 100 \mathrm{~mL}$ & $50-200$ & $518 \pm 19$ & $480 \pm 25$ & $<800$ & 540 \\
\hline Citrate & $\mathrm{mg} / 100 \mathrm{~mL}$ & - & $90^{(\mathrm{d})}$ & - & 100 & - \\
\hline $\mathrm{Cl}$ & $\mathrm{mg} / 100 \mathrm{~mL}$ & 110 & $121 \pm 7$ & $106 \pm 6$ & $91-110$ & 199 \\
\hline $\mathbf{P}$ & $\mathrm{mg} / 100 \mathrm{~mL}$ & $32-96$ & $60 \pm 8$ & $47 \pm 6$ & $44-90$ & - \\
\hline $\mathrm{Ca}$ & $\mathrm{mg} / 100 \mathrm{~mL}$ & $40-60$ & $112 \pm 14$ & $96 \pm 12$ & $43-160$ & - \\
\hline $\mathbf{K}$ & $\mathrm{mg} / 100 \mathrm{~mL}$ & 160 & $128 \pm 13$ & $128 \pm 13$ & $143-182$ & - \\
\hline Mg & $\mathrm{mg} / 100 \mathrm{~mL}$ & - & $19.4 \pm 2.7$ & $15.6 \pm 2.2$ & 9 & - \\
\hline $\mathrm{Na}$ & $\mathrm{mg} / 100 \mathrm{~mL}$ & 50 & $41.1 \pm 2.3$ & $43.3 \pm 2.4$ & $40-61$ & $228 \pm 23$ \\
\hline Lactose & $\mathrm{g} / \mathrm{L}$ & $46-52$ & $43.0 \pm 1.6$ & $34.9 \pm 1.3$ & $38-49$ & 40 \\
\hline Ratio(LA/LT) & - & $0.01-0.04$ & 0.12 & 0.14 & - & 0.14 \\
\hline $\mathrm{pH}$ & - & $5.9-6.3$ & $4.3-4.6$ & $4.3-4.6$ & $4.0-4.6$ & 4.6 or $6^{(\mathrm{e})}$ \\
\hline Conductivity & $\mathrm{mS} / \mathrm{cm}$ & - & $8.27 \pm 0.42$ & $7.77 \pm 0.38$ & - & 7.80 \\
\hline Total Anions & $\mathrm{meq} / \mathrm{L}$ & - & $>140$ & $>120$ & - & 120 \\
\hline
\end{tabular}

(a) The range of values are collated from the composition and characteristics of raw acid whey from the production of fresh cheese and casein. 
(b) Conducted by DTS Food Laboratory, North Melbourne, Victoria, Australia, using Method FATS 07 12.99 .

${ }^{\text {(c) } B y ~ B r a d f o r d ~ p r o t e i n ~ a n a l y s i s, ~ u s e d ~ a s ~ a n ~ i n d i c a t i o n ~ o f ~ t h e ~ p r e s e n c e ~ o f ~ p r o t e i n ~ o n l y . ~}$

(d) Conducted by DTS Food Laboratory, North Melbourne, Victoria, Australia, using Method CITA 03 12.94 .

(e) Adjusted using $10 \mathrm{M} \mathrm{NaOH}$.

Table 2: Properties of Neosepta ion exchange membranes.

\begin{tabular}{l|c|cc}
\hline \multirow{2}{*}{ Properties } & \multirow{2}{*}{ Unit } & \multicolumn{2}{|c}{ Membranes } \\
\cline { 3 - 4 } & & AHA (AEM) & \multicolumn{1}{c}{ CMB (CEM) } \\
\hline Type & - & Strong Base (Cl type) & Strong Acid (Na type) \\
\hline Electrical resistance & ohm.cm2 & 4.1 & 4.5 \\
\hline Thickness & $\mathrm{mm}$ & 0.22 & 0.21 \\
\hline Temperature tolerance & ${ }^{\circ} \mathrm{C}$ & $0-60$ & $0-60$ \\
\hline pH tolerance & - & $0-14$ & $0-14$ \\
\hline
\end{tabular}

\subsection{Electrodialysis}

The electrodialysis experiments were conducted using an FT-ED-40 module manufactured by FuMA-Tech GmbH (Germany). The ED module consists of two titanium-iridium plasma coated stainless steel electrodes. The module was set with two pairs of cation and anion exchange membranes with alternating diluate and concentrate spacers. In order to prevent migration of anions to the electrode compartment, a third cation exchange membrane was employed at the cathode [26]. The effective area per ion exchange membrane is $36 \mathrm{~cm}^{2}$. The potential difference was generated by a DC power supply (Agilent DC Modular Power System N6764A) with an output voltage range of 0-60 V and output current range of 0-20 A. The electrodialysis unit was operated with a constant voltage of $7 \mathrm{~V}$ across the ED stack. At this voltage, the current density declined from $130-300 \mathrm{~A} / \mathrm{m}^{2}$ to $10-50 \mathrm{~A} / \mathrm{m}^{2}$, depending on the operating temperature and the degree of salt removal. Operating at constant voltage is preferred in batch operation since it reduces the possibility of operating the stack beyond the limiting current density of the system [27]. This in term reduces water splitting which may occur when the conductivity of the solution changes over time in a batch process, or 
along the flow path of the stack during a large scale continuous operation. Water splitting is known to decrease current efficiency and result in a dramatic shift in $\mathrm{pH}$, making the electrodialysis process uneconomical [28].

Three peristaltic pumps (Masterflex L/S digital drive 600 RPM with Masterflex L/S high performance pump head) were used to deliver the electrode, diluate and concentrate solutions to the ED module. The flow rate of the electrode solution was $1,000 \mathrm{~mL} / \mathrm{min}$ per chamber, whereas the flow rate of the diluate and concentrate was $125 \mathrm{~mL} / \mathrm{min}$ per cell, as recommended by FuMA-Tech. These flowrates were also verified by Lim et al. [29] to provide for the effective elimination of the boundary layer resistance to mass transfer.

The experiments were conducted in batch mode. The electrode, diluate and concentrate solutions (with $1.2 \mathrm{~L}$ initial volume) were re-circulated in three separate tanks. These tanks were kept in a water bath with temperature control. The solution in each tank was mixed using a magnetic stirrer in order to obtain homogeneous solutions. Samples (approximately $10 \mathrm{~mL}$ each) from each stream were collected throughout the experiments for analysis. To minimise microbial growth/spoilage in dairy processing, operating temperatures are typically chosen to be below $5{ }^{\circ} \mathrm{C}$ or above $45^{\circ} \mathrm{C}[30,31]$. Hence, the experiments were run at $5{ }^{\circ} \mathrm{C}, 30{ }^{\circ} \mathrm{C}$ and $45{ }^{\circ} \mathrm{C}$ for the artificial solutions and at $5{ }^{\circ} \mathrm{C}$ and $45{ }^{\circ} \mathrm{C}$ for the acid whey samples. To determine the impact of lactic acid dissociation, experiments were conducted at both $\mathrm{pH} \sim 4.6$ and $\mathrm{pH} 6$, except for the skimmed acid whey samples, which were conducted at their natural $\mathrm{pH}$. All experimental runs were repeated at least twice and the data presented is the average of two trials. The electrodialysis stack was cleaned-in-place by flushing the units with deionised water for 15 minutes, followed by circulating $0.05 \mathrm{M} \mathrm{HCl}$ and $0.05 \mathrm{M} \mathrm{NaOH}$ for 15 minutes in sequence. This was then followed by flushing with deionised water for 20 minutes.

The power consumption was determined as the product of the applied voltage and the measured current. The degree of demineralisation was estimated based on the total removal of cations and anions. The current efficiency was estimated using the following equation:

$\eta=\frac{F\left(V_{D, \text { initial }} \sum z_{j} \cdot C_{D, j, \text { initial }}-V_{D, \text { final }} \sum z_{j} \cdot C_{D, j, \text { final }}\right)}{n \int I d t} \times 100 \%$ 
where $V_{D \text {,initial }}$ and $V_{D \text {,final }}$ are the initial and final volumes of the diluate solution respectively, $C_{D, j, \text { initial }}$ and $C_{D, j, \text { final }}$ the initial and final concentration of ion $j$ in the diluate tank, $z_{j}$ the valence of the ion $j, F$ the Faraday constant $(96,485 \mathrm{C} / \mathrm{mole}), n$ the number of cell pairs, $I$ the current and $t$ the time [9]. The current efficiencies for the artificial solutions were calculated based on the concentration of anions (i.e. lactate and chloride), whereas cation concentrations (sodium, potassium, calcium, magnesium) were used for the acid whey samples, as these contained some anions whose concentrations could not be readily determined, such as phosphate.

\subsection{Sample Analysis}

Total solids and total ash contents were determined as per Australian Standards AS 2003.1.1 and AS 2003.1.5. Acid whey samples were weighed before drying at $110{ }^{\circ} \mathrm{C}$ for more than 12 hours in a fan forced oven to evaporate all moisture. After weighing, the dried samples were further charred in a furnace at $650^{\circ} \mathrm{C}$ overnight until samples turned white.

Bradford protein analysis was used to estimate protein content. Briefly, a Bio-Rad Coomassie blue dye reagent $(5 \mathrm{ml})$ was mixed with $100 \mu \mathrm{l}$ of the acid whey sample. The absorbance of the prepared sample was measured at $595 \mathrm{~nm}$ and compared against a linear calibration curve constructed using standard solutions of bovine serum albumin (BSA, $\geq 99 \%$, lyophilized powder, Sigma-Aldrich) according to the manufacturer's instructions.

The concentrations of sodium, potassium, calcium, magnesium and phosphorus were determined using Inductively Coupled Plasma Atomic Emission Spectroscopy (ICP-OES 720ES, Varian), using detection wavelengths of $589.59 \mathrm{~nm}, 766.49 \mathrm{~nm}, 422.67 \mathrm{~nm}, 279.55 \mathrm{~nm}$ and $213.62 \mathrm{~nm}$, respectively. The analysis was performed in axial view using a robust $40 \mathrm{MHz}$ plasma system. Argon gas was utilised to purge the system with plasma and auxiliary flowrates of 15 and $1.5 \mathrm{~L} / \mathrm{min}$, respectively. The flow through the nebulizer was adjusted to $0.75 \mathrm{~L} / \mathrm{min}$. Lactate, chloride and lactose concentrations were determined using highperformance liquid chromatography (HPLC). An Aminex HPX-87H ion exclusion column (BIORAD) was used with a mobile phase of $0.009 \mathrm{~N} \mathrm{H}_{2} \mathrm{SO}_{4}$ at $0.6 \mathrm{ml} / \mathrm{min}$ and $60^{\circ} \mathrm{C}$. Lactate ions 
were detected by a UV-Vis detector (at a wavelength of $220 \mathrm{~nm}$ and $285 \mathrm{~nm}$ wavelengths), while chloride and lactose were detected by a Refractive Index Detector (RID).

Diluate samples of the skimmed and ultrafiltered acid whey after electrodialysis were freeze-dried using a freeze drier for 3 days. The glass transition temperature of the resulting dried powder was measured using Differential Scanning Calorimetry (DSC 8500, PerkinElmer).

\section{RESULTS AND DISCUSSION}

\subsection{Transfer of lactate ions}

The removal of lactate ions from solution as a function of time is shown in Figure 1. In general, the lactate ions are removed faster at higher temperatures, as the resistance of the membrane [32] and the solution is lower [33]. The solution viscosity is also lower at a higher temperature $\left(1.52 \mathrm{CP}\right.$ at $10^{\circ} \mathrm{C}$ vs $0.68 \mathrm{CP}$ at $45^{\circ} \mathrm{C}$ for a $4.93 \%$ lactose solution [34]), aiding lactate removal. For the artificial solutions at $5{ }^{\circ} \mathrm{C}$, the initial rate of lactate ion removal in the first 60 minutes is slower than that in the last 120 minutes. This is because chloride ions are removed preferentially to lactate ions via the anion exchange membranes (Figure 2). After most of the chloride ions are transferred, the electrical energy is utilized predominately to remove lactate ions. This phenomenon is not apparent at higher temperatures, as it only takes about 60 minutes for most of the chloride ions to be removed at $45^{\circ} \mathrm{C}$, but 180 minutes is required at $5^{\circ} \mathrm{C}$. 


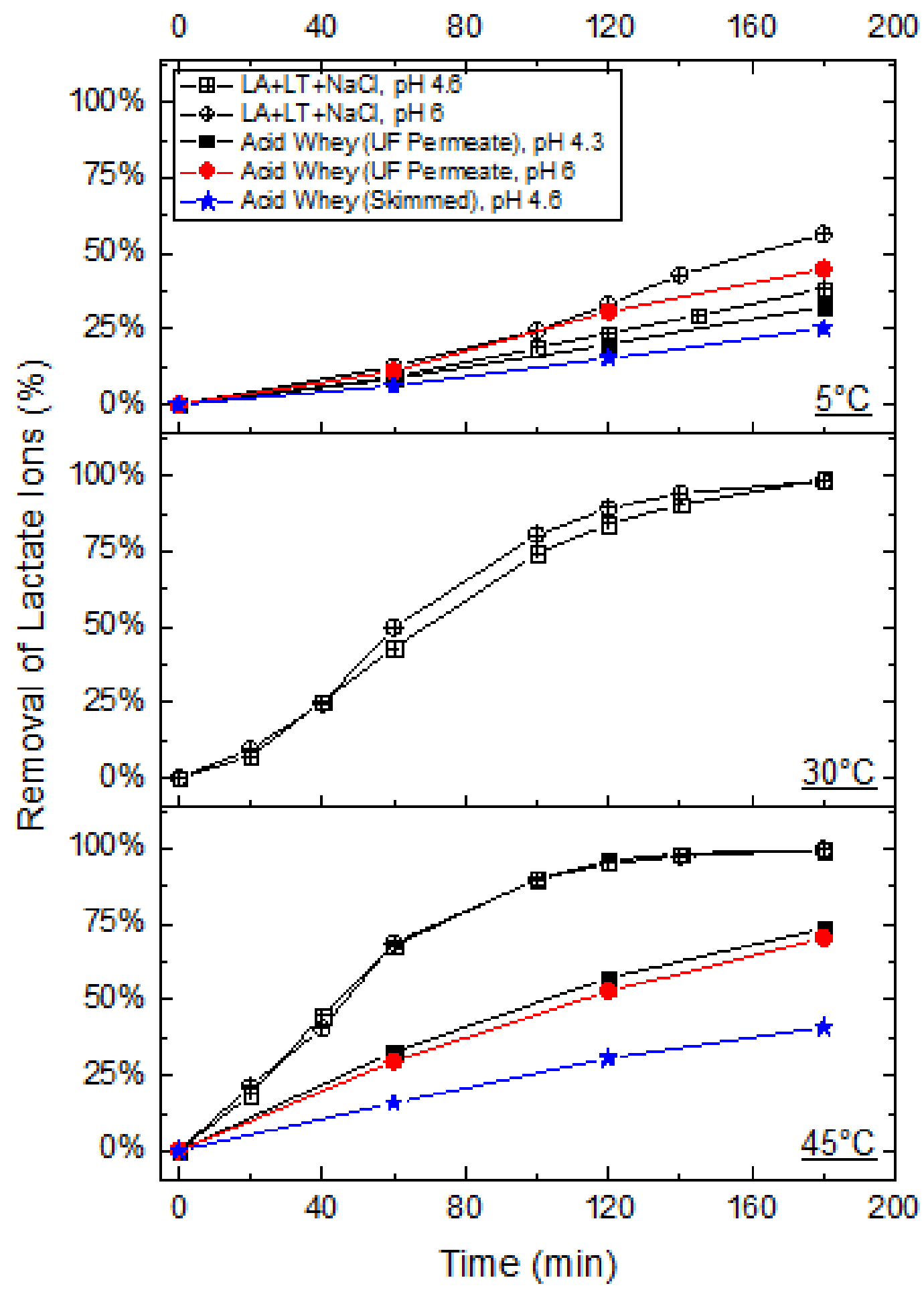

Figure 1: Removal of lactate ions from the diluate over time.

The impact of $\mathrm{pH}$ on the transfer rate of the lactate ions was only observed at $5^{\circ} \mathrm{C}$. Due to the higher degree of dissociation of lactic acid at higher $\mathrm{pH}(75 \%$ and $99 \%$ dissociation at $\mathrm{pH}$ 4.6 and 6 respectively, estimated using Equation 2), the rate of lactate ion transfer is slightly 
higher at $\mathrm{pH} 6$ than that at $\mathrm{pH}$ 4.6. This effect is diminished with increasing temperature, for both of the artificial solutions and the acid whey samples. This is because the rate of ion transfer is much faster and the degree of lactic acid dissociation is also greater at higher temperatures. Using Equation 2, it is estimated that $86 \%$ and $90 \%$ of lactic acid is dissociated at $\mathrm{pH} 4.6$ at $30^{\circ} \mathrm{C}$ and $45^{\circ} \mathrm{C}$, respectively.

The rate of lactate ion removal from the acid whey samples is slower than that from the artificial solutions at 5 and $45^{\circ} \mathrm{C}$, due to the more complex nature of the acid whey. Other than chloride and lactate ions, acid whey also contains phosphate and citrate which are larger and can be present as multivalent species. Citrate is the conjugate base of a triprotic acid and phosphate may exist as $\mathrm{PO}_{4}{ }^{3-}, \mathrm{HPO}_{4}{ }^{2-}$, or $\mathrm{H}_{2} \mathrm{PO}_{4}{ }^{-}$, depending on the solution equilibria. In addition, there are other organic species that might be charged and contribute to current utilisation. Therefore, the actual concentration of total anions in acid whey is greater than that in the simple monovalent artificial solutions (Table 1). 


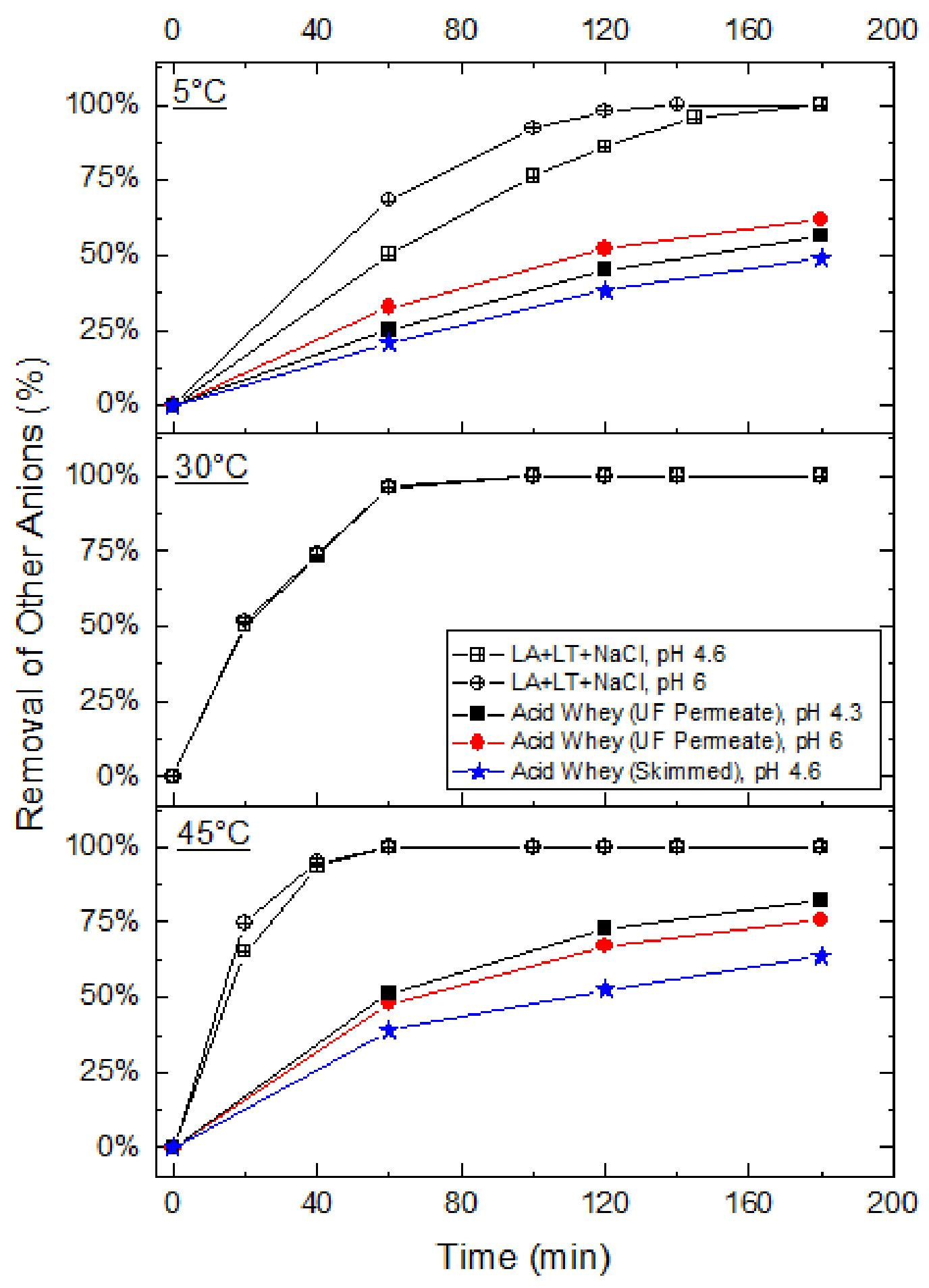

Figure 2: Removal of anions other than lactate from the diluate as a function of time. For the model artificial solutions, these anions are purely chloride. For acid whey systems, these anions include citrate, chloride and phosphate.

The specific removal of individual anions after 180 minutes, based on solution analysis, is shown in Table 3. In general, chloride ions are removed preferentially to lactate and 
phosphate ions, possibly due to the smaller molecular weight and Stokes radius of chloride (35.5 Da, $0.12 \mathrm{~nm}$ ) compared to other anions (e.g. lactate: $89.1 \mathrm{Da}, 0.23 \mathrm{~nm} ; \mathrm{H}_{2} \mathrm{PO}_{4}$ : $97 \mathrm{Da}$, $0.28 \mathrm{~nm}$ ) [35]. After the chloride ions are mostly removed from the artificial solution at $45^{\circ} \mathrm{C}$, all the available current is used to migrate the lactate ions, hence achieving a complete removal of lactic acid within 180 minutes. In contrast, the lactate ions in the acid whey must compete against citrate and phosphate ions after most of the chloride ions are removed. This is the reason why the lactic acid removal is lower for the real acid whey than for the artificial solutions. For the skimmed acid whey samples, the percentage of removal is smaller than that in the ultrafiltered acid whey, possibly due to an increase in the boundary layer thickness caused by the presence of fat and protein fouling the membrane (see Table 1) [10]. For the same reason, the current densities were observed to be $17 \%-30 \%$ higher for the ultrafiltered acid whey samples, compared to that for the skimmed acid whey samples.

Table 3: Percentage of anions removed from model artificial and acid whey solutions after 180 minutes of a batch electrodialysis process.

\begin{tabular}{c|c|c|c|c}
\hline Temperature & Feed (pH 4.3-4.6) & Lactate & Chloride & Phosphate \\
\hline \multirow{3}{*}{$5{ }^{\circ} \mathrm{C}$} & $\mathrm{LA}+\mathrm{LT}+\mathrm{NaCl}$ & $38 \%$ & $100 \%$ & - \\
\cline { 2 - 5 } & Acid whey (UF Permeate) & $33 \%$ & $86 \%$ & $32 \%$ \\
\cline { 2 - 5 } & Acid whey (Skimmed) & $25 \%$ & $76 \%$ & $28 \%$ \\
\hline \multirow{3}{*}{$45^{\circ} \mathrm{C}$} & LA+LT+NaCl & $99.7 \%$ & $100 \%$ & - \\
\cline { 2 - 5 } & Acid whey (UF Permeate) & $74 \%$ & $91 \%$ & $73 \%$ \\
\cline { 2 - 5 } & Acid whey (Skimmed) & $41 \%$ & $84 \%$ & $45 \%$ \\
\hline
\end{tabular}

The current efficiency indicates the proportion of the electrical current that is being usefully used to move ions. The values calculated here increase slightly with temperature reflecting increasing solution conductivity, from $\sim 80 \%$ at $5^{\circ} \mathrm{C}$ to $\sim 90 \%$ at $45^{\circ} \mathrm{C}$ (Figure 3). No apparent difference is observed, however, within experimental error, between the two $\mathrm{pH}$ values and the two types of solutions. Overall, the current efficiencies indicate good electrodialysis performance under the conditions tested here. 


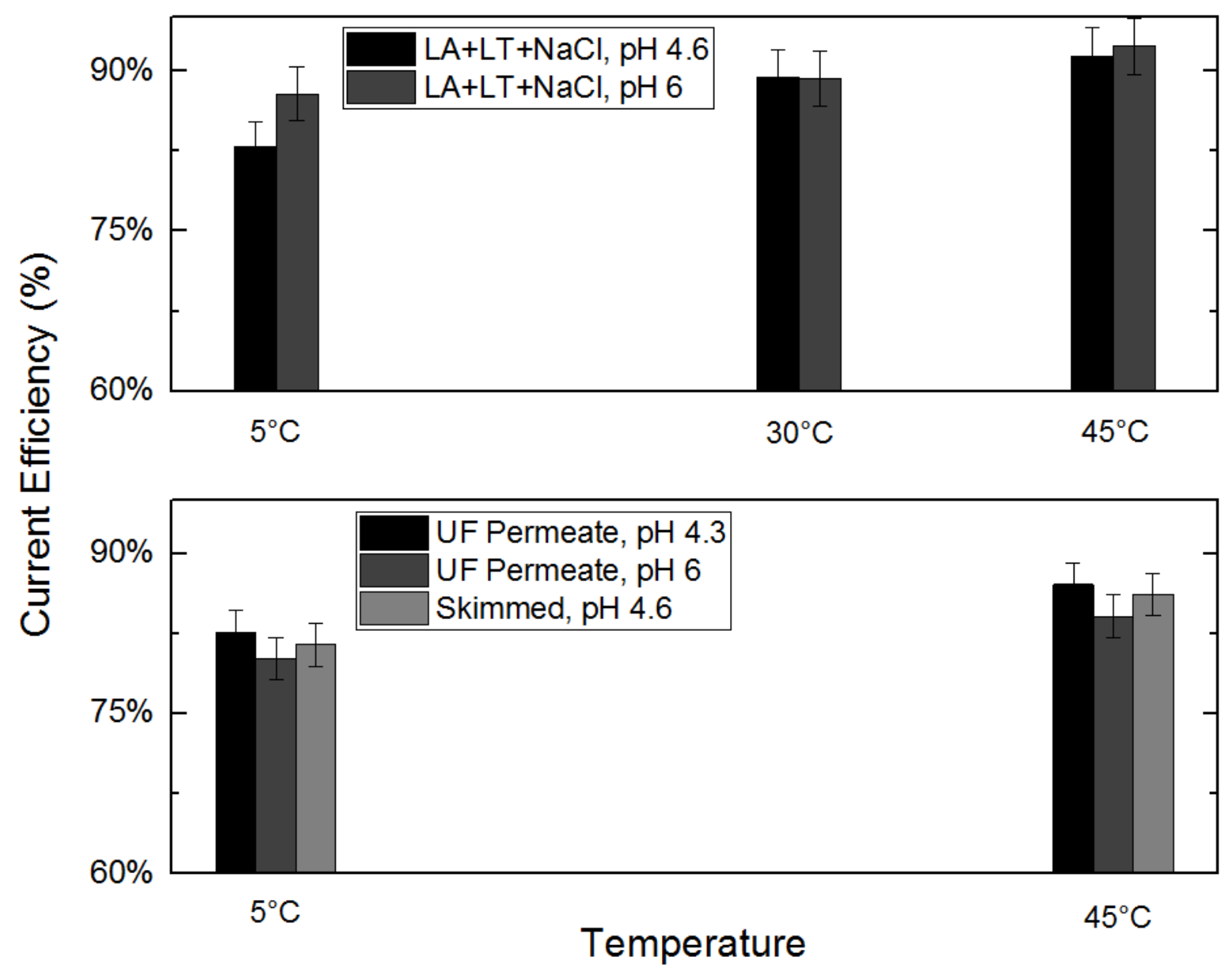

Figure 3: Current efficiency calculated for the batch electrodialysis experiments using model artificial and acid whey solutions.

\subsection{Demineralisation and Energy Consumption}

The ultrafiltered acid whey at its natural $\mathrm{pH}\left(\mathrm{pH} \mathrm{4.3)}\right.$ was demineralized further at $45^{\circ} \mathrm{C}$, to provide a lactate/lactose ratio comparable to sweet whey (0.01-0.04 g LA/g LT). During this process, the conductivity of the diluate solution and the ratio of LA/LT decreased while the degree of demineralization increased (Figure $4 a$ ). Removal of $80 \%$ of the lactate ions corresponded to removal of about $90 \%$ of the total mineral content. As shown in Figure $4 b$, the power consumption and the specific energy required to remove one unit of lactate ion decreased with decreasing conductivity due to the depletion of competing ions in the solution. The $\mathrm{pH}$ declines by half a unit within the first 200 minutes, a phenomenon which was also observed by others during whey demineralisation using electrodialysis [10, 36]. This could be caused by further dissociation of lactic acid due to the removal of lactate ions, 
which shifts the equilibrium shown in Equation 1. In addition, some water splitting may have occurred. However, the stable $\mathrm{pH}$ recorded at lower conductivity values and the high current efficiencies at $45^{\circ} \mathrm{C}$ suggest that this is only a minor phenomenon. A lower voltage could be used to reduce this effect but this change would be at the cost of a much larger membrane area in a continuous operation.

The crossover of lactose from the diluate to the concentrate compartments is very low at $\sim 5$ $\mathrm{mg} / \mathrm{m}^{2} \mathrm{~s}$, meaning that almost all of the lactose can be effectively retained for conversion into value-added products downstream. 

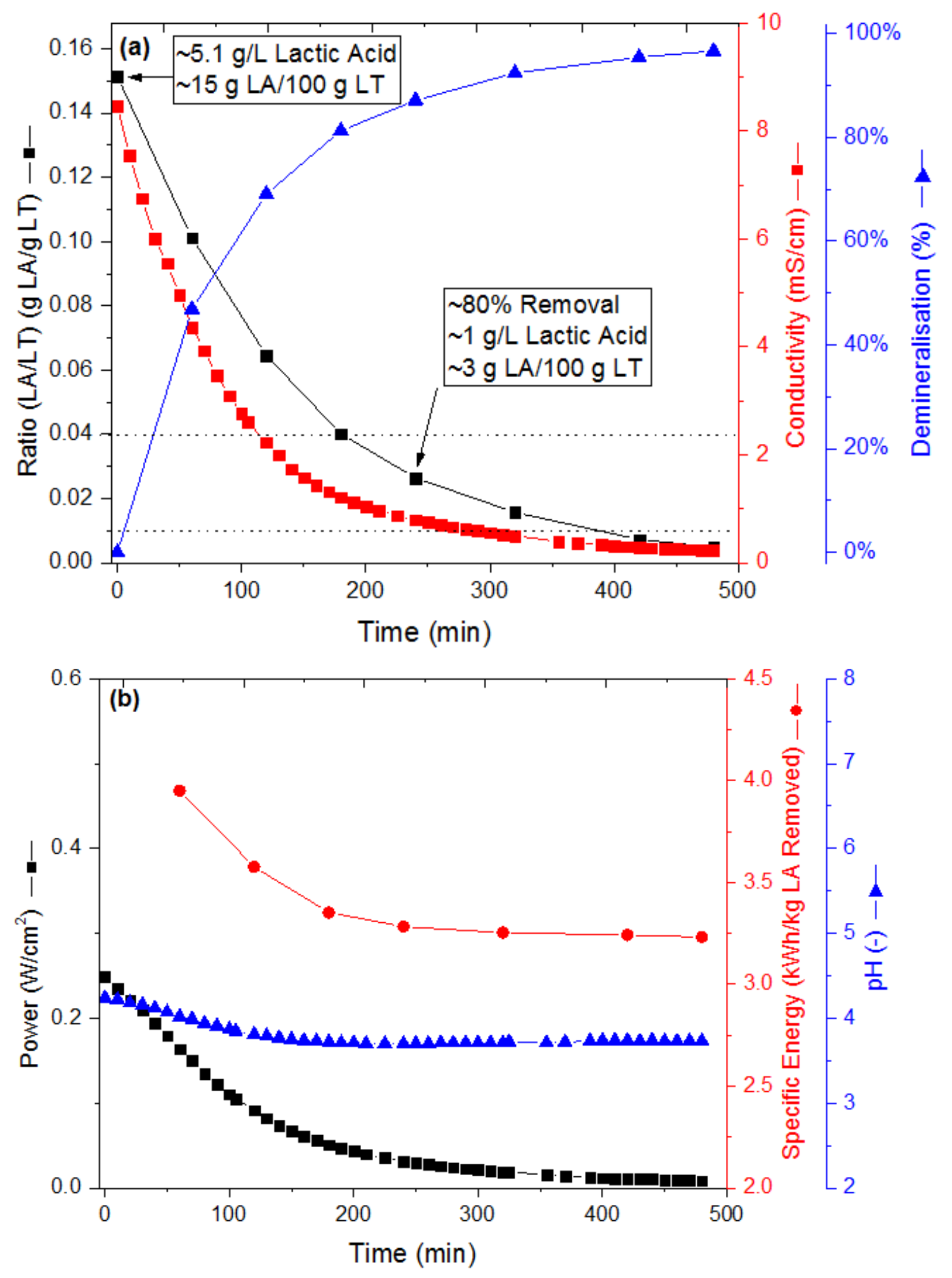
Figure 4: Performance during batch electrodialysis of ultrafiltered acid whey $(\mathrm{pH} 4.3)$ at $45{ }^{\circ} \mathrm{C}$. The conductivity and $\mathrm{pH}$ data shown are for the diluate stream.

The removal of individual anions and cations as a function of time is presented in Figure 5. The removal of potassium $\left(\mathrm{K}^{+}\right)$and sodium $\left(\mathrm{Na}^{+}\right)$ions is faster than the removal of calcium $\left(\mathrm{Ca}^{2+}\right)$ and magnesium $\left(\mathrm{Mg}^{2+}\right)$, possibly due to the greater mobility, the lower ionic radius $[10,37,38]$ and the greater electrical conductivity [38] of these monovalent ions. Similar trends have been observed by others in skimmed milk and whey demineralization [10, 39, 40] and in reverse osmosis concentrate reclamation [41] using similar strongly acidic cation exchange membranes including SC-1 (Stantech, Inc.), CMS-1 (Neosepta) and PC-SK (PCA Polymerchemie Altmeier $\mathrm{GmbH}$, Heusweiler, Germany). The rate of removal of the anions follows the order presented in Table 3.

The level of demineralization for all samples is presented in Figure 6, as a function of the percentage of lactate ion removal from the diluate stream. Although each data point represents a different time point in the batch experiments, a clear trend is observed. This implies that while the membrane area will be largest for removal of a certain percentage of lactate ions from a skimmed whey solution at low temperature, the overall level of demineralization will be the same. 


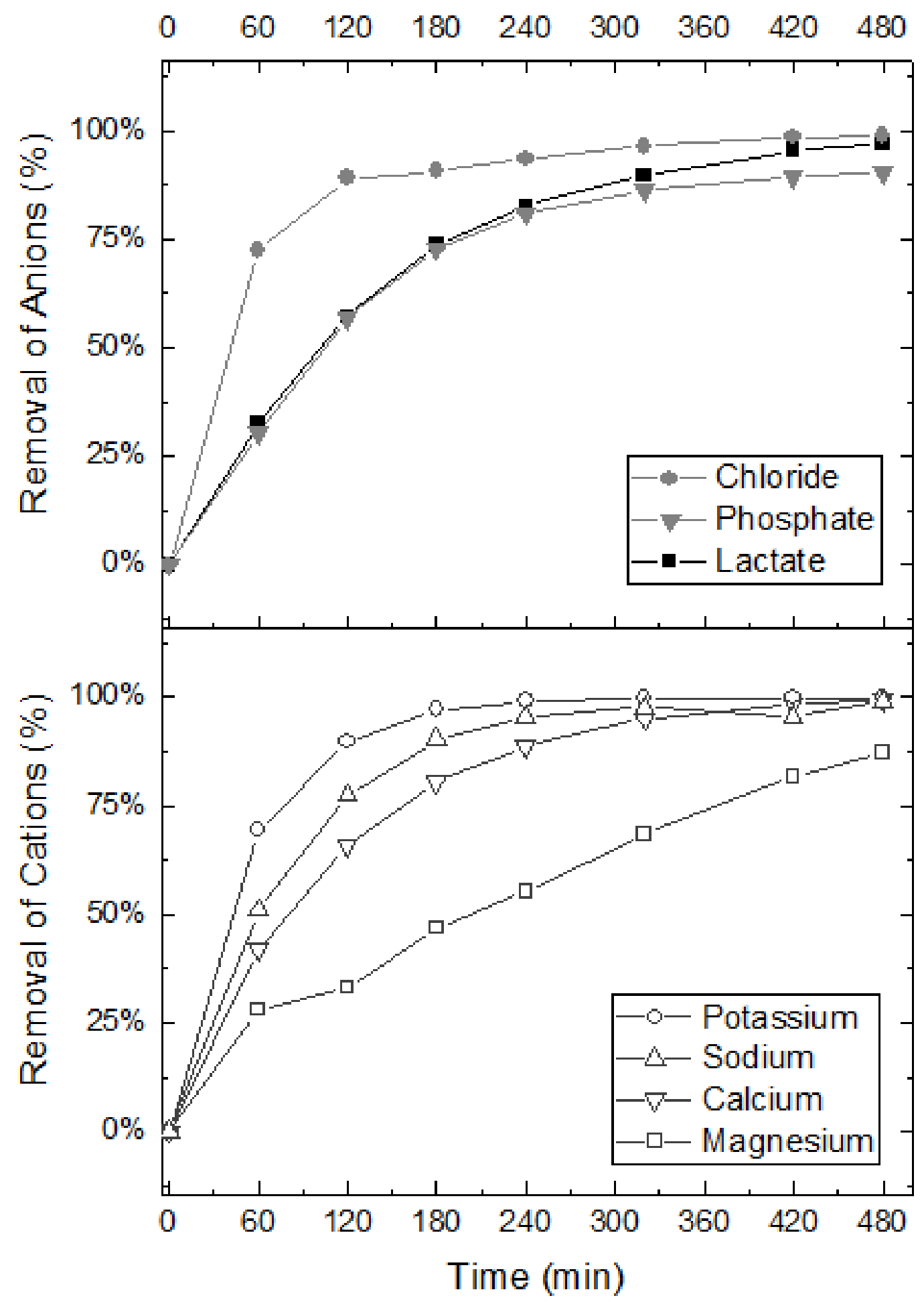

Figure 5: Removal of anions and cations from ultrafiltered acid whey $(\mathrm{pH} 4.3)$ at $45^{\circ} \mathrm{C}$ as a function of time for the batch operation of the electrolysis. 


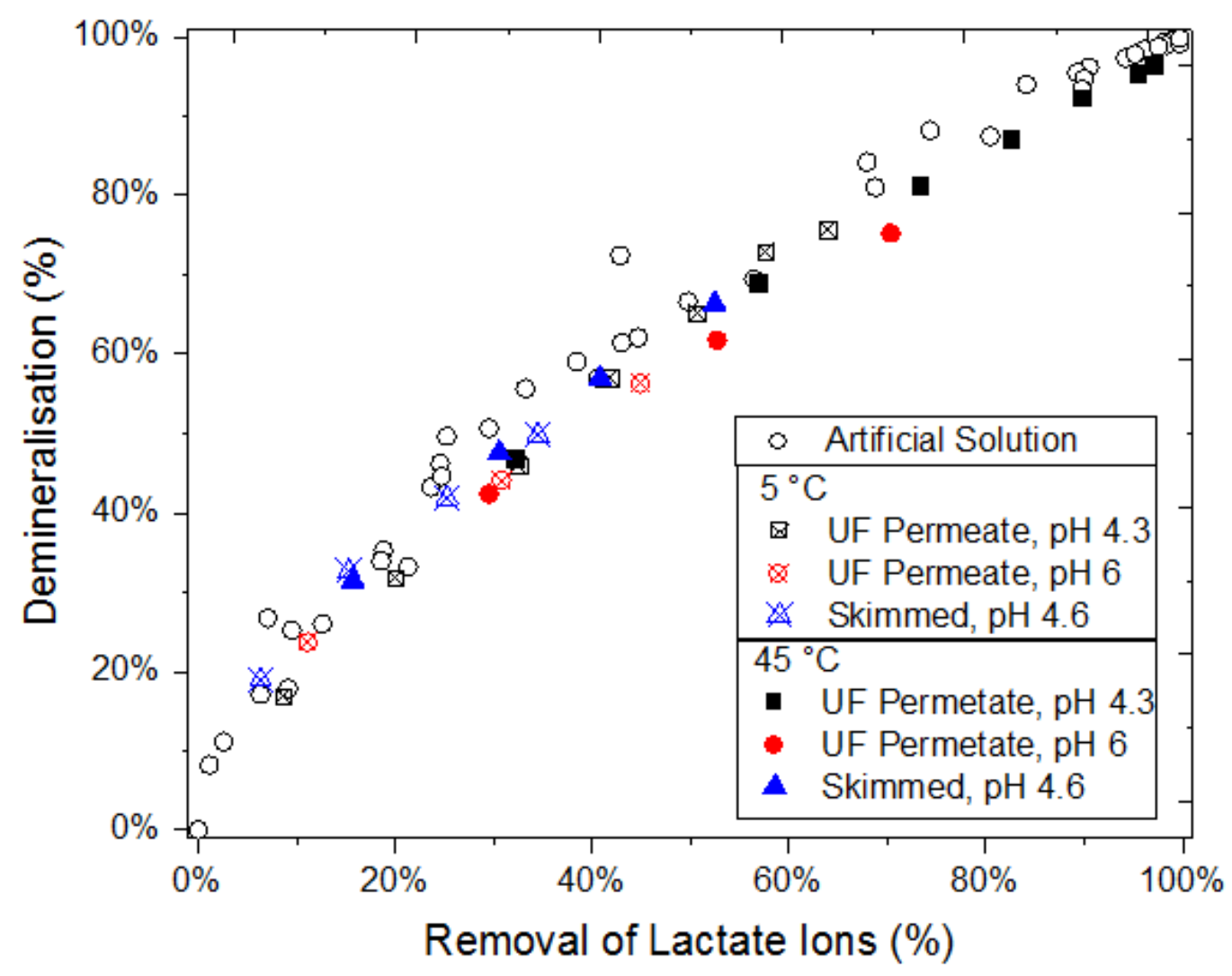

Figure 6: Correlation between the degree of demineralization and the percentage of removal of lactate ions from model artificial and acid whey solutions.

Similarly, the energy consumption per kilogram of lactic acid removed is essentially independent of the solution composition (Figure 7). More energy is required to remove the first $40 \%$ of the lactic acid, because during this period, energy is also consumed to remove chloride and other anions (Figures 2 and 5). Once these anions are depleted from the diluate, the specific energy consumption plateaus to a value of $3 \mathrm{kWh}$ per $\mathrm{kg}$ of lactic acid. 


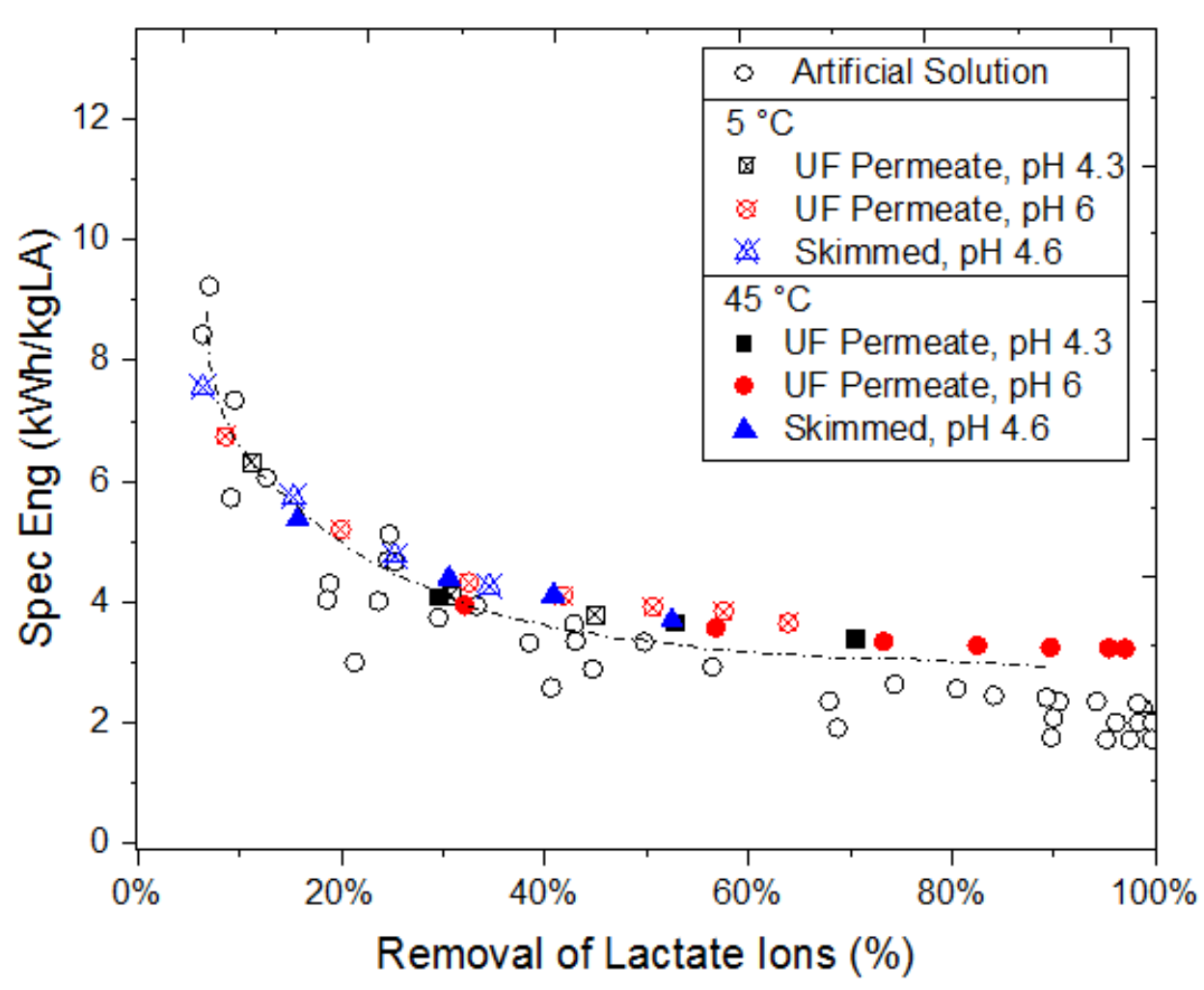

Figure 7: Specific energy required as a function of the percentage removal of lactate ions for model artificial and acid whey solutions.

The energy consumption per kg of whey processed for an initial lactate concentration of 5.1 $\mathrm{g} / \mathrm{L}$ is comparable, if a little higher than values reported in the literature for sweet whey (Figure 8). This is expected as sweet whey and acid whey are very similar in composition. Moreover, the ion exchange membranes used in this work are relatively high in mechanical strength, which imposes a higher electrical resistance (Table 2 ) on the system, leading to a higher energy consumption. The energy consumption may also be over-estimated due to the fact that the electrodialysis unit is small and was operated in batch mode. 




Figure 8: Energy consumption for different degrees of whey demineralization (based on $5.1 \mathrm{~g} / \mathrm{L}$ of LA in acid whey). Data from MEGA a.s. (a ED technology provider inCzech Republic) [42] and Greiter et al. (demineralisation of sweet whey, starting with $18-20 \%$ TS) [11] are plotted for comparison.

\subsection{Glass transition temperature}

The glass transition temperatures of the acid whey samples (both skimmed and ultrafiltered) after electrodialysis to remove lactate ions are presented in Figure 9. In general, as the ratio of lactic acid to lactose decreases, the glass transition temperature of the powder increases. After removing $80 \%$ of the lactate ions from the ultrafiltered acid whey, the glass transition temperature of the freeze-dried powder increases from $\sim 80^{\circ} \mathrm{C}$ to $\sim 95^{\circ} \mathrm{C}$. The magnitude of increase is similar for the skimmed acid whey powder, with the glass transition temperatures being $\sim 15^{\circ} \mathrm{C}$ lower. The change in glass transition temperature is comparable to that reported by Saffari and Langrish [7] and Shrestha et al. [2], where laboratory solutions of lactic acid, lactose and whey protein isolate were processed in a small scale spray drier. The present results generally provide higher glass transition temperatures for the ultrafiltered acid whey permeate, which may reflect the lower protein concentration in this sample. The most significant result, however, is the clear evidence that 
removal of lactate increases the glass transition temperature. This physical change should reduce stickiness issues previously observed in the spray drying operation of acid whey, allowing effective recovery of these solutions.

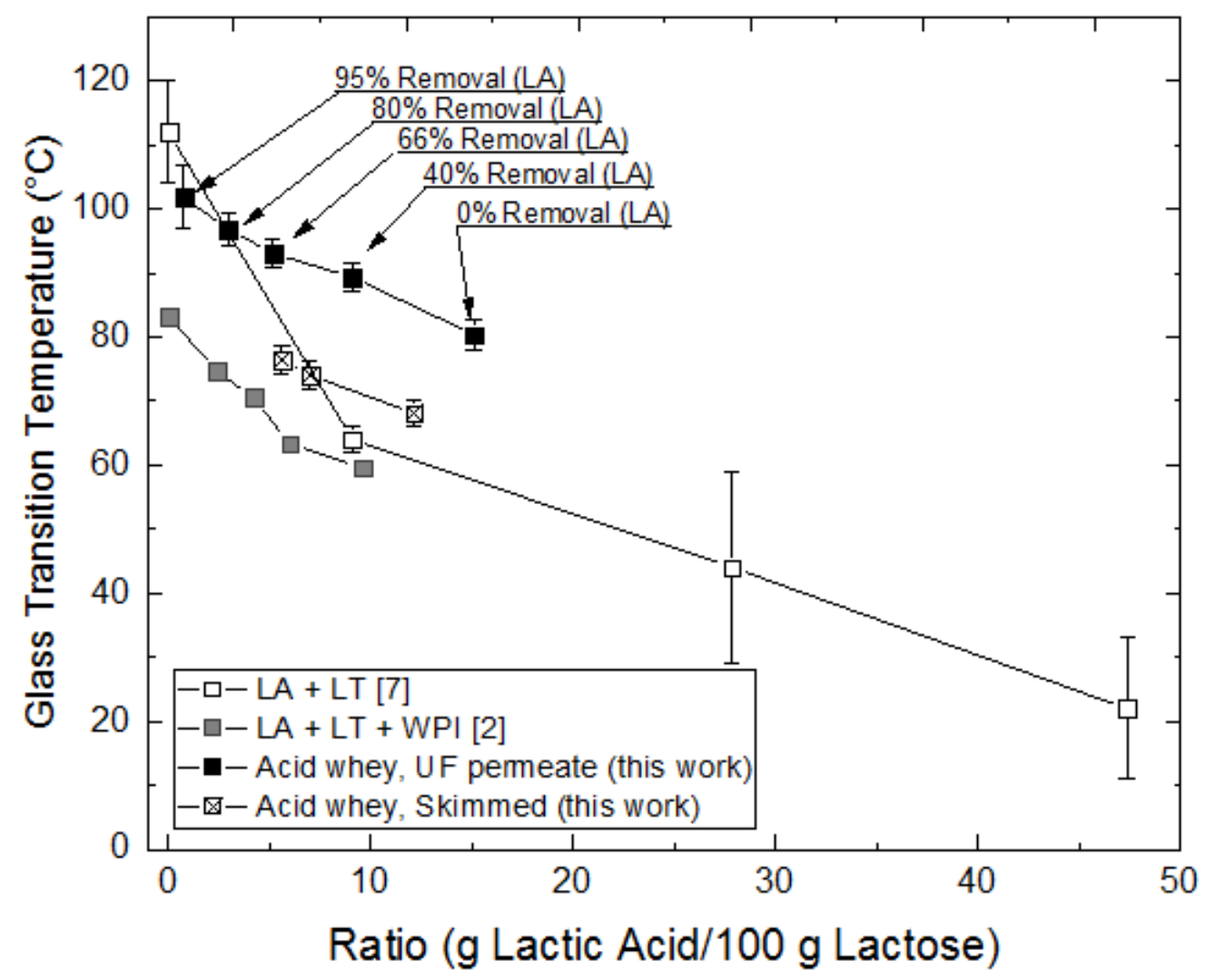

Figure 9: Glass transition temperature ( $\mathrm{Tg}$ ) of freeze-dried acid whey powder, and that of the spraydried sweet whey powder reported by Shrestha et al. (model lactic acid, lactose and whey protein isolate solution) [2] and Saffari and Langrish (model lactic acid and lactose solution) [7].

\section{CONCLUSIONS}

Electrodialysis was operated in batch mode to remove the lactate ions from acid whey at three temperatures and two solution $\mathrm{pH}$, typical of the operating conditions in dairy streams. For both the artificial solutions and the acid whey samples, the lactate ions were removed at a slower rate compared to other anions present in acid whey, but the removal of these ions was more efficient at higher operating temperatures. The rate of removal was also improved slightly by increasing the $\mathrm{pH}$ from 4.6 to 6 at $5^{\circ} \mathrm{C}$. A change in temperature from $30^{\circ} \mathrm{C}$ to $45^{\circ} \mathrm{C}$ also aided acid whey recovery. When $80 \%$ of the lactate ions were removed to achieve the similar ratio of lactic acid to lactose as found in sweet whey, $90 \%$ of the 
minerals were simultaneously removed. It was found that $\sim 0.014 \mathrm{kWh}$ is required to process $1 \mathrm{~kg}$ of acid whey and achieve $90 \%$ demineralization. The use of ultrafiltration was found to assist demineralization and the use of nanofiltration upstream to reduce chloride levels [11] could possibly further reduce this energy consumption significantly, as the electrodialysis operation would then be more focused on lactate removal. Due to the effective removal of lactate ions, this study illustrates that acid whey could be processed by electrodialysis to make whey powder with 90\% demineralization (D90), a valuable ingredient for manufacturing infant formulas, in the same way as sweet whey via conventional spray drying operations.

\section{ACKNOWLEDGEMENT}

This research was supported under Australian Research Council's Industrial Transformation Research Program (ITRP) funding scheme (project number IH120100005). The ARC Dairy Innovation Hub is a collaboration between The University of Melbourne, The University of Queensland and Dairy Innovation Australia Ltd. 


\section{REFERENCES}

[1] R.M. Benitez, G.M. Ortero, Whey : types, composition and health implications / Rafael Mauro Benitez and Gustavo M. Ortero, editors, Hauppauge, N.Y. : Nova Science Publishers, c2012., 2012. [2] A.K. Shrestha, B.P. Adhikari, T.E. Howes, B.R. Bhandari, Effect of lactic acid on spray drying behavior of acid-whey and study of their glass transition temperature, Journal of Food Science and Technology Nepal, 2 (2006) 57-62.

[3] H.W. Modler, D.B. Emmons, Calcium as an Adjuvant for Spray-Drying Acid Whey, Journal of Dairy Science, 61 294-299.

[4] A.K. Salameh, L.S. Taylor, Role of Deliquescence Lowering in Enhancing Chemical Reactivity in Physical Mixtures, The Journal of Physical Chemistry B, 110 (2006) 10190-10196.

[5] M.E. Knipschildt, G.G. Andersen, Drying of Milk and Milk Products, in: R.K. Robinson (Ed.) Robinson: Modern Dairy Technology, Springer US, 1994, pp. 159-254.

[6] R. Early, Technology of Dairy Products, Springer, 1998.

[7] M. Saffari, T. Langrish, Effect of lactic acid in-process crystallization of lactose/protein powders during spray drying, Journal of Food Engineering, 137 (2014) 88-94.

[8] E. Gyo Lee, S.-H. Moon, Y. Keun Chang, I.-K. Yoo, H. Nam Chang, Lactic acid recovery using twostage electrodialysis and its modelling, Journal of Membrane Science, 145 (1998) 53-66.

[9] Y.-J. Wee, J.-S. Yun, Y.Y. Lee, A.-P. Zeng, H.-W. Ryu, Recovery of lactic acid by repeated batch electrodialysis and lactic acid production using electrodialysis wastewater, Journal of Bioscience and Bioengineering, 99 (2005) 104-108.

[10] A. Pérez, L.J. Andres, R. ÁLvarez, J. Coca, C.G. Hill, Electrodialysis of whey permeates and retentates obtained by ultrafiltratio, Journal of Food Process Engineering, 17 (1994) 177-190. [11] M. Greiter, S. Novalin, M. Wendland, K.-D. Kulbe, J. Fischer, Desalination of whey by electrodialysis and ion exchange resins: analysis of both processes with regard to sustainability by calculating their cumulative energy demand, Journal of Membrane Science, 210 (2002) 91-102. [12] S. Budavari, The Merck Index: An Encyclopedia of Chemicals, Drugs, and Biologicals, Merck \& Company, 1989.

[13] D. Perrin, The effect of temperature on pK values of organic bases, Australian Journal of Chemistry, 17 (1964) 484-488.

[14] A.W. Williams, H.A. Kline, Electrodialysis of acid whey, in, Google Patents, 1980.

[15] L. Bazinet, Electrodialytic Phenomena and Their Applications in the Dairy Industry: A Review, Critical Reviews in Food Science and Nutrition, 44 (2005) 525-544.

[16] T. Steinhauer, J. Schwing, S. Krauß, U. Kulozik, Enhancement of ultrafiltration-performance and improvement of hygienic quality during the production of whey concentrates, International Dairy Journal, 45 (2015) 8-14.

[17] B. Ruiz, P. Sistat, P. Huguet, G. Pourcelly, M. Araya-Farias, L. Bazinet, Application of relaxation periods during electrodialysis of a casein solution: Impact on anion-exchange membrane fouling, Journal of Membrane Science, 287 (2007) 41-50.

[18] S. Mikhaylin, V. Nikonenko, G. Pourcelly, L. Bazinet, Hybrid bipolar membrane electrodialysis/ultrafiltration technology assisted by a pulsed electric field for casein production, Green Chemistry, (2015).

[19] R.J. Durham, J.A. Hourigan, Waste management and co-product recovery in dairy processing, in: K. Waldron (Ed.) Handbook of Waste Management and Co-Product Recovery in Food Processing, Volume 1, Woodhead Publishing Limited and CRC Press LLC, 2009, pp. 332-387.

[20] G. Bylund, Whey processing, in: T. AB (Ed.) Dairy processing handbook, Tetra Pak Processing Systems AB, S-221 86 Lund, Sweden, 1995.

[21] K.M. Blaschek, W.L. Wendorff, S.A. Rankin, Survey of Salty and Sweet Whey Composition from Various Cheese Plants in Wisconsin, Journal of Dairy Science, 90 (2007) 2029-2034. 
[22] S.S. Nair, V.V. Mistry, K.R. Nauth, Reduction of Salt (NaCl) Losses During the Manufacture of Cheddar Cheese, Journal of Dairy Science, 87 (2004) 2831-2838.

[23] M. Nguyen, N. Reynolds, S. Vigneswaran, By-product recovery from cottage cheese production by nanofiltration, Journal of Cleaner Production, 11 (2003) 803-807.

[24] E. Spreer, Milk and Dairy Product Technology, Taylor \& Francis, 1998.

[25] C. Peri, W.L. Dunkley, REVERSE OSMOSIS OF COTTAGE CHEESE WHEY. 1. Influence of

Composition of the Feed, Journal of Food Science, 36 (1971) 25-30.

[26] Y. Kim, W.S. Walker, D.F. Lawler, Electrodialysis with spacers: Effects of variation and correlation of boundary layer thickness, Desalination, 274 (2011) 54-63.

[27] J. Boye, Y. Arcand, Green Technologies in Food Production and Processing, Springer New York, 2012.

[28] H. Strathmann, Electrodialysis, a mature technology with a multitude of new applications, Desalination, 264 (2010) 268-288.

[29] J. Lim, A. Aguiar, C.A. Scholes, L.F. Dumée, G.W. Stevens, S.E. Kentish, Monoethanolamine Reclamation Using Electrodialysis, Industrial \& Engineering Chemistry Research, 53 (2014) 1931319321.

[30] R.R. Mahoney, Modification of Lactose and Lactose-Containing Dairy Products with $\beta$ Galactosidase, in: P.F. Fox (Ed.) Developments in Dairy Chemistry-3, Springer Netherlands, 1985, pp. 69-109.

[31] N.C. Beaton, Ultrafiltration and Reverse Osmosis in the Dairy Industry - An Introduction to Sanitary Considerations, Journal of Food Protection, 42 (1979) 584-590.

[32] A.H. Galama, D.A. Vermaas, J. Veerman, M. Saakes, H.H.M. Rijnaarts, J.W. Post, K. Nijmeijer, Membrane resistance: The effect of salinity gradients over a cation exchange membrane, Journal of Membrane Science, 467 (2014) 279-291.

[33] A. Bernardes, M.A.S. Rodrigues, J.Z. Ferreira, Electrodialysis and Water Reuse: Novel Approaches, Springer, 2013.

[34] K.R. Morison, F.M. Mackay, VISCOSITY OF LACTOSE AND WHEY PROTEIN SOLUTIONS, International Journal of Food Properties, 4 (2001) 441-454.

[35] A. Bouchoux, H. Roux-de Balmann, F. Lutin, Investigation of nanofiltration as a purification step for lactic acid production processes based on conventional and bipolar electrodialysis operations, Separation and Purification Technology, 52 (2006) 266-273.

[36] L. Diblíková, L. Čurda, K. Homolová, Electrodialysis in whey desalting process, Desalination and Water Treatment, 14 (2010) 208-213.

[37] B. Van der Bruggen, A. Koninckx, C. Vandecasteele, Separation of monovalent and divalent ions from aqueous solution by electrodialysis and nanofiltration, Water Research, 38 (2004) 1347-1353.

[38] L. Bazinet, D. Ippersiel, C. Gendron, J. Beaudry, B. Mahdavi, J. Amiot, F. Lamarche, Cationic balance in skim milk during bipolar membrane electroacidification, Journal of Membrane Science, 173 (2000) 201-209.

[39] H. Šímová, V. Kysela, A. Černín, Demineralization of natural sweet whey by electrodialysis at pilot-plant scale, Desalination and Water Treatment, 14 (2010) 170-173.

[40] L.J. Andrés, F.A. Riera, R. Alvarez, Skimmed milk demineralization by electrodialysis: Conventional versus selective membranes, Journal of Food Engineering, 26 (1995) 57-66.

[41] Y. Zhang, K. Ghyselbrecht, B. Meesschaert, L. Pinoy, B. Van der Bruggen, Electrodialysis on RO concentrate to improve water recovery in wastewater reclamation, Journal of Membrane Science, 378 (2011) 101-110.

[42] MEGA a.s., Main characteristics of the MEGA a.s. ED-technology Installation, in, Czech Republic, 2015. 


\section{University Library}

\section{- M M N E R VA A gateway to Melbourne's research publications}

Minerva Access is the Institutional Repository of The University of Melbourne

Author/s:

Chen, GQ;Eschbach, FII;Weeks, M;Gras, SL;Kentish, SE

Title:

Removal of lactic acid from acid whey using electrodialysis

Date:

2016-01-28

Citation:

Chen, G. Q., Eschbach, F. I. I., Weeks, M., Gras, S. L. \& Kentish, S. E. (2016). Removal of lactic acid from acid whey using electrodialysis. SEPARATION AND PURIFICATION TECHNOLOGY, 158, pp.230-237. https://doi.org/10.1016/j.seppur.2015.12.016.

Persistent Link:

http://hdl.handle.net/11343/123252 